\title{
The Effect of Agile Manufacturing on Logistics Performance: The Case of Textile Sector
}

\author{
Emel GELMEZ iD a Muammer ZERENLER iD b \\ a Selçuk University, Faculty of Economics and Administrative Science, Department of Business Administration, Konya, Turkey. \\ emelgelmez@selcuk.edu.tr \\ b Selçuk University, Faculty of Economics and Administrative Science, Department of Business Administration, Konya, Turkey. \\ zerenler@selcuk.edu.tr
}

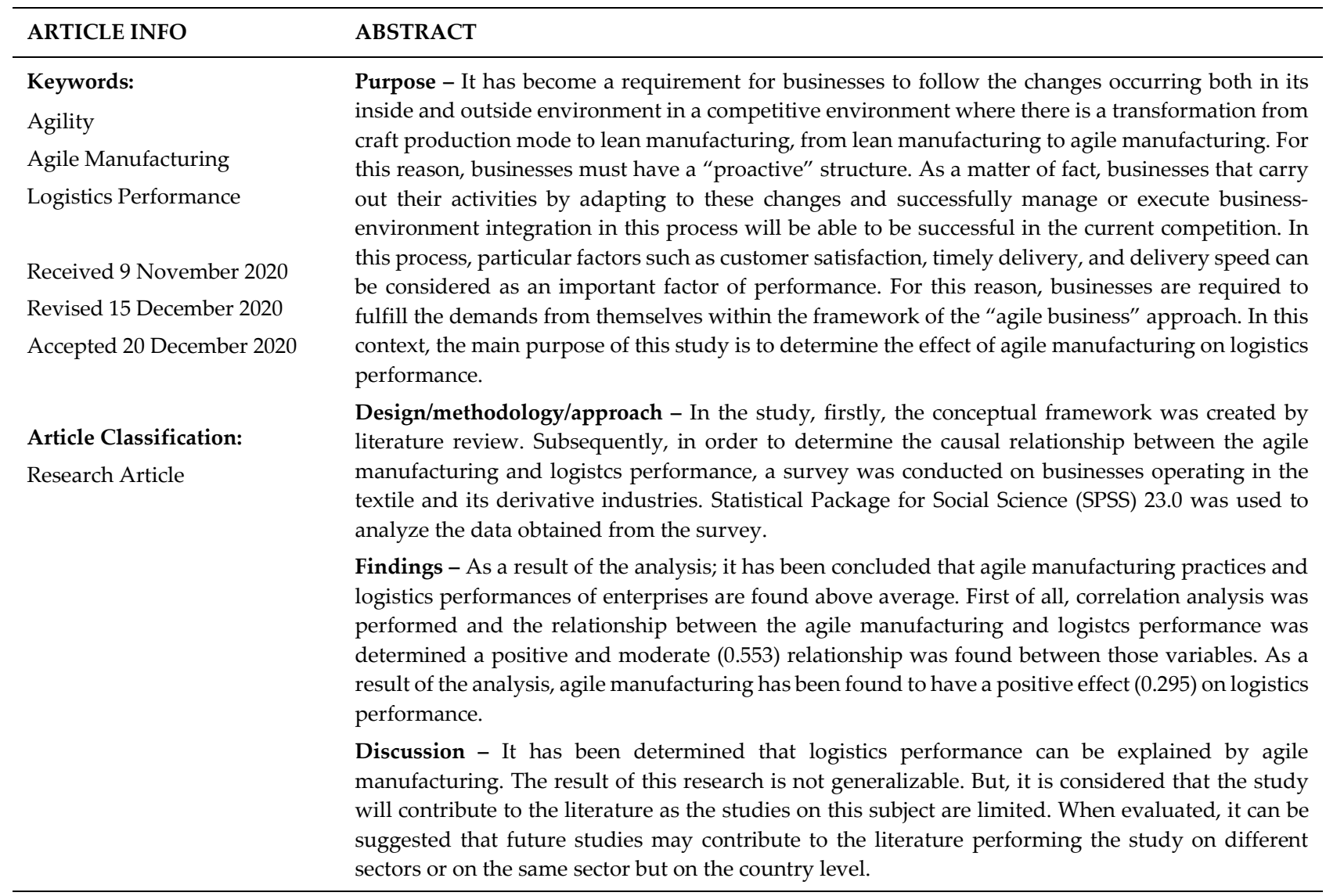

\section{INTRODUCTION}

Today's businesses in current markets are facing more severe changes than ever before. In this way, meeting the market demand becomes difficult in an ever-changing environment. Therefore, agility allows manufacturers to gain competitive advantage by responding quickly and in an experienced manner to market changes (Lee et al., 2020). As a matter of fact, today, businesses are trying to improve their production activities in line with their needs in order to overcome the increasing competition intensity. Thus, it seeks different ways of improvement depending on the analysis of the needs of the current market. One of these ways is agile manufacturing (Hallgren and Olhager, 2009: 976-977).

Increasing competition as a result of globalization (Aktepe, 2019:47) requires businesses to constantly evaluate their business strategies to take advantage of the driving forces of rapidly changing markets (Udokporo et al., 2020). It is important for businesses which seek to be successful in this process to fulfill the requirements of competition within the agile business models. Agile manufacturing strategies, which may have a significant impact on the increase in operation performance, have a significant effect on maintaining competitive

\section{Suggested Citation}

Gelmez, E., Zerenler, M. (2020). The Effect of Agile Manufacturing on Logistics Performance: The Case of Textile Sector, Journal of Business Research-Turk, 12 (4), 4142-4150. 


\section{E. Gelmez - M. Zerenler 12/4 (2020) 4142-4150}

advantage. In this regard, this study examines the relationship of cause and effect between variables by investigating the relationship between logistics performance and agile manufacturing, which is one of the important components of performance. As a result of the literature review, it is considered that the study will contribute to the literature as the studies on this subject are limited.

Within the scope of the study, first of all, the conceptual framework of agile manufacturing is depicted and its relationship with logistics performance is examined in the context of the literature. Then, detailed information about the survey method conducted to test the basic hypothesis determined within the framework of the research question of the study was given and the analyzes made were examined.

\section{CONCEPTUAL FRAMEWORK}

\subsection{Agile Manufacturing}

Examination of the historical process of production shows that it has evolved from the mass production system to lean manufacturing over the past century. Numerous methods such as cellular production and continuous improvement have been developed between these two poles. The main elements of each of these are to increase the responsiveness and effectiveness of the operation with the ultimate goals, which is to reduce the lead times and stock levels while improving quality (Timms et al., 2000). According to Goldman and Nagel (1993) and Goldman et al. (1995) companies are constantly focusing on change and innovation in order to achieve competitive advantage over their competitors. In this environment, the changes occurring in the environment tend to occur much more rapidly (Meade and Sarkis, 1999: 241). Today, businesses are forced to change along with globalization that eliminates local borders, changes in competition conditions and with rapid developments in technology. In this environment where uncertainty is felt intensely, it is very difficult for businesses to keep up with changes with traditional methods (Kasap and Peker, 2009: 58). A new paradigm known as "agility" is one of the ways to achieve competitive advantage in this new environment (Meade and Sarkis, 1999: 241). At this point, agile manufacturing is perceived as a vital feature that businesses need in order to maintain their competitive advantages in the new world order (Sharifi and Zhang, 2001: 773).

The use of agile manufacturing in the same sense as flexibility or response speed implies its narrow use (Güzel, 2013: 184). It is such that agile manufacturing can be defined as the ability of businesses to survive in a continuous and competitive environment and continue to develop (Gunesekaran, 1999a: 1; Gunasekaran, 1999b: 87). At the same time, agile manufacturing is a new production paradigm with high efficiency and quality, enabling fast and effective action in the constantly changing markets, consisting of products and services that the customer wants (Cho and Jung, 1996: 324). In a more general way, agile production is to respond in a conscious, effective and coordinated way with the change occurring in the business environment by creating an information and communication infrastructure, combining technology, human resources and organization, providing flexibility, speed, quality, service and efficiency (Vázquez- Bustelo et al., 2007: 1308).

A new or significantly improved product or process gains importance in internal applications, workplace organization or external relations (Aktepe and Çiftçi, 2017: 836). At the same time, businesses take customer expectations into account to achieve competitive advantage (Agarwal et al., 2006: 211). The agile manufacturing paradigm is concerned with production activities based on the variable demands of customers (Thilak et al., 2015: 1). Agile manufacturing system is thus a solution method considering that there is no single production sector in which there is no change nowadays. One of the basic elements of agile manufacturing is to gain from change (Tanoğlu, 2018: 39). In this respect, when it is evaluated in terms of producer and consumer, it is important to examine the concept of agile manufacturing.

\subsection{Logistics and Logistics Performance}

Various changes have occurred in the business world since the early 1990s. With the effect of globalization, the structure of competition has evolved as the customer demands the right material at the lowest cost, at the right time, at the right point and in the right situation. Outsourcing logistics functions enable an enterprise to focus on its core competencies. In this way, businesses can take advantage of the best resources by allowing a world-class solution provider to professionally manage their logistics and take advantage of technology and personnel infrastructure. Therefore, logistics has become an indispensible part of every business today (Neeraja et al., 2014: 666). Indeed, logistics creates value for customers, suppliers and stakeholders of businesses (Ballou, 1997: 118). 


\section{E. Gelmez - M. Zerenler 12/4 (2020) 4142-4150}

Logistics is the process of strategically managing the supply, movement and storage of materials, parts and finished stocks through the organization and marketing channel (Christopher, 2011: 2) and a function responsible for the movement of all materials throughout the supply chain (Başkol, 2010: 49). At this point, logistics activities can be considered as an operational component of supply chain management, including measurement, supply, inventory management, transportation and fleet management, as well as data collection and reporting (USAID, 2011: 1).

Logistics performance enables the manufacturer business to measure the performance other than the manufacturer or the supplier. Bowersox et al. (2000) defines logistics performance as a reflection of supply chain superiority (Green et al., 2007: 275-276). Logistics performance is an expression of how much has been achieved or how close it is to set standards for the objectives, policies, strategies, tactics, plans and objectives created for the logistic sector or the logistics companies or the service output that they achieve at the end of a certain period within the framework of their own strategic plans or their own predetermined logistics duties (Bayat and Özdemir, 2016: 604). At the same time, this performance criterion refers to the quality and competence of logistics services and the timely delivery of products to the buyer, and can be expressed as a measure of the success and effectiveness of logistics activities. In this regard, logistics performance is the ability of logistics services to meet the changing and diversified demands of the industry, the contribution of efficiency in logistics processes to the performance and competitiveness of enterprises, the added value gain created by logistics activities (Bayraktutan and Özbilgin, 2015: 98). Thus, the relationship between agile manufacturing and cause and effect has been examined in the study by taking into consideration the logistic performance, which has an important place in the performance measurements of the enterprises.

\subsection{Relationship of Agile Manufacturing and Logistics Performance}

When the respective literature is examined, it is seen that the basic variables that form the subject of the study are handled separately. Some of these studies are summarized as follows.

Sezen et al. (2002) studied the effects of production, marketing and logistics functions on business performance in businesses. As a result of their analysis, it is concluded that the general operation performance to be obtained with the effective coordination of these functions will be higher than the performance to be obtained under normal working conditions. In their study, especially the importance of the combination of production and logistics functions and the binding role of logistics function between production and marketing functions are studied.

Sezen (2005) concluded that the overall business performance achieved when there is an effective coordination between functions can be well above the performance achieved when tasks are performed individually. At the same time, it is found that the logistic functions have an important place in linking operational activities and marketing activities of businesses.

Vázquez-Bustelo et al. (2007) carried out their study in order to analyze the agile manufacturing system in Spain and to examine whether agile manufacturing in different sectors is a critical factor. In the study, it was concluded that agile manufacturing affects the operating performance by increasing the production powers.

In his study on the textile sector, Zerenler (2007) developed the information technology, agile manufacturing and business performance conceptual model of the companies that are placed in ISO 500 list. As a result of the analysis, it was concluded that information technologies have positive effects on business performance.

Green et al. (2007) concluded that logistics performance has a significant impact on organizational performance.

In his study, Ustasüleyman (2008) examined the effect of competitive capacity and agility coercers on business performance and did not determine the effect of competitive capacity on agility capacity. In the study, three basic variables were determined as agility coercers, competitive capacity and business performance. Within the scope of the study, the relationships between the variables and hypotheses were tested by structural equation modeling. All three hypotheses established to determine the relationships between the variables have been accepted. 


\section{E. Gelmez - M. Zerenler 12/4 (2020) 4142-4150}

Zelbst et al. (2010) tested the effects of agile manufacturing on operational and logistics performance based on the relationship between market orientation, just-in-time production, total quality management and agile manufacturing. Significant and positive relationships were found between the variables.

Inman et al. (2011) determined that enterprises with high manufacturing agility have a positive relationship on the operational, marketing and financial performance of agile manufacturing.

Iqbal et al. (2018) in their study on 248 Pakistani ready-garment export businesses associated the concept of agile manufacturing with a variety of concepts. It has been concluded that agile manufacturing is related to operational, marketing and financial performance of businesses.

Nabass and Abdallah (2019) examined the effect of agile manufacturing on business performance. At the same time, the effect of agile manufacturing on operational performance was examined through operational performance factors (cost, quality, speed, flexibility). As a result of the analysis, it has been concluded that agile manufacturing has a direct and positive effect on the performance of the company.

In the literature review, it is observed that the variables determined as agile manufacturing and logistics performance are studied and examined in some ways. In this context, research question within the scope of the study is "Does agile manufacturing have an impact on logistics performance?". Thus, the following basic hypothesis has been determined.

Hypothesis: Agile manufacturing has a positive effect on logistics performance.

\section{RESEARCH METHOD AND SAMPLING}

The questionnaire method was used in order to create the data set of the study and the questions were asked by using Likert scale. Based on the textile enterprises within the Konya Chamber of Industry ${ }^{1}$, an applied research based on survey method was conducted. Online and face-to-face interview method has been applied to perform the questionnaires.

Simple random sampling gives an equal chance to be selected for sampling each of the items in the research universe (Gürbüz and Şahin, 2018: 135). In order to use this method, the information about the problem or hypothesis handled should be homogeneous compared to the main population (Islamoğlu and Alnıaçık, 2016: 197). Therefore, simple random sampling method was used in the study.

In the study, the possible sample mass figures table developed by Yazıcıŏlu and Erdoğan (2014: 89) that could represent a specific mass was used in determining the sample mass. 133 businesses operating in textile and derivative sector operate in the field where the study is carried out. As a result of the application, 65 questionnaire forms were obtained suitable for the evaluation

In order to determine the agile manufacturing level of the enterprise, "Agile Manufacturing Scale" which was used by Iqbal et al. (2018) and Zelbst et al. (2010) in their studies was used. In order to determine the logistics performance levels of businesses, "Logistics Performance Scale" which Zelbst et al. (2010) used in their studies was used.

Before the research hypothesis was tested, the reliability of the scales used was tested. In this context, the information regarding the reliability of the scales is depicted in Table 1 below.

Table 1. Cronbach's Alpha $(\alpha)$ Values of the Scales Used

\begin{tabular}{l|c|c}
\hline Scale & Item Number & $\begin{array}{c}\text { Cronbach's Alpha } \\
(\boldsymbol{\alpha})\end{array}$ \\
\hline Agile Manufacturing & 10 & 0.857 \\
\hline Logistics Performance & 6 & 0.760 \\
\hline
\end{tabular}

As indicated in Table 1, while agile manufacturing cronbach's alpha $(\alpha)$ value is 0.857 ; logistics performance cronbach's alpha $(\alpha)$ value is 0.760 . $\alpha$ value must be at least 0.70 (Gürbüz and Şahin, 2018: 333). At this point,

\footnotetext{
${ }^{1}$ There are 133 businesses operating in textile and its derivative industries in Konya. These data were obtained from the Konya Chamber of Industry Presidency on 22.11.2019. At the same time, the surveys were conducted in December 2019.
} 


\section{E. Gelmez - M. Zerenler 12/4 (2020) 4142-4150}

$\alpha$ values of the scales tested in this study is over the acceptable lower limit, which is 0.70 , as in several studies (Sekaran, 2003: 311; Altunışık, 2010: 124). Therefore, the scales used in the study are considered to be reliable.

\section{EVALUATON OF RESEARCH FINDINGS}

\subsection{Properties of the Sample}

$35 \%$ of the participants in the research had a staff numbering between $10-49$, and $31 \%$ of them have $50-249$ personnel. At the same time, it is seen $34 \%$ had less than 10 personnel. Accordingly, it can be suggested that the businesses within the scope of the study are SMEs. At the same time, it has been determined $85 \%$ of the enterprises in the analysis unit have completely domestic capital; and that $15 \%$ constitute the capital structures with foreign partnerships.

After analyzing the demographic structure of the enterprises, the level of agile manufacturing practices was measured. Accordingly, the findings of enterprises regarding agile manufacturing are presented in Table 2.

Table 2. Findings Related to Agile Manufacturing of Enterprises

\begin{tabular}{l|c|c}
\hline Agile Manufacturing & Mean & $\begin{array}{c}\text { Standard } \\
\text { Deviation }\end{array}$ \\
\hline Our managers have the necessary knowledge and skills to manage change. & 4.35 & 0.80 \\
\hline $\begin{array}{l}\text { We react instantly to associate with the changes in the market into our } \\
\text { production processes and systems. }\end{array}$ & 4.29 & 0.84 \\
\hline We establish cooperative relationships with customers and suppliers. & 4.00 & 0.97 \\
\hline $\begin{array}{l}\text { Our strategic vision emphasizes the need for flexibility and agility in order to } \\
\text { respond to changes in the market. }\end{array}$ & 4.03 & 0.98 \\
\hline $\begin{array}{l}\text { We have the skills to detect and predict changes in the market. } \\
\text { We have the appropriate technology and technological capabilities to respond } \\
\text { quickly to changes in customer demand. }\end{array}$ & 3.80 & 1.11 \\
\hline $\begin{array}{l}\text { Our production processes are flexible in terms of product models and } \\
\text { configurations. }\end{array}$ & 3.77 & 1.00 \\
\hline $\begin{array}{l}\text { We have the ability to deliver products to customers in time and respond } \\
\text { quickly to changes in delivery requirements. }\end{array}$ & 3.69 & 0.95 \\
\hline We can rapidly launch new products to the market. & 3.37 & 1.02 \\
\hline $\begin{array}{l}\text { We have the ability to meet and exceed the product quality levels demanded by } \\
\text { our customers. }\end{array}$ & 3.03 & 0.87 \\
\hline Total & 2.92 & 0.87 \\
\hline
\end{tabular}

Notes: (i) $n=65$, (ii) In the scale $1=I$ definitely disagree with and $5=I$ definitely agree with mean. (iii) According to Friedman two ways ANOVA test $(\chi 2=170.736 ; p<.001)$ the results are statistically significant.

When the table is analyzed in general terms, it is seen that agile manufacturing practices are above the middle value (3.73). Among the questions asked to determine the agility of businesses; while the expression "our managers have the necessary knowledge and skills to manage change" has the highest value (4.35); this value is followed by the expression "We react instantly to associate with the changes in the market into our production processes and systems" (4.29). However, the item "We have the ability to meet and exceed the product quality levels demanded by our customers" appears to have the lowest value (2.92). This is an indication that businesses need to make improvements in quality levels, while the ability to respond quickly to changes in the market is rather good. However, in general terms, it can be suggested that the agility features of the enterprises are at a good level.

Findings related to logistics performance, which have an important effect on determining the performance criteria of enterprises, are depicted in Table 3. 
E. Gelmez - M. Zerenler 12/4 (2020) 4142-4150

Table 3. Findings Regarding Logistics Performance

\begin{tabular}{lcc}
\hline Logistics Performance & Mean & Standard Deviation \\
\hline Delivery reliability & 3.80 & 0.51 \\
\hline Delivery speed & 3.48 & 0.71 \\
\hline Customer satisfaction & 3.26 & 0.76 \\
\hline Order filling capacity & 3.23 & 0.58 \\
\hline Responsiveness & 3.22 & 0.65 \\
\hline Delivery flexibility & 3.20 & 0.56 \\
\hline Total & 3.36 & $\mathbf{0 . 4 3}$ \\
\hline
\end{tabular}

Notes: (i) $n=65$, (ii) In the scale $1=$ worse than competitors and $5=I$ better than competitors. (iii) According to Friedman two ways ANOVA test ( $\chi 2=62.154 ; p<.001)$ the results are statistically significant.

It is observed that the logistics performances of the companies within the scope of the research are above the middle value (3.36). Thus, it can be suggested that their performance cannot be considered bad in general terms. As a matter of fact, when the logistics performance criteria are analyzed on the basis of each item, the highest value has "delivery reliability" (3.80), and this is followed by "delivery speed" (3.48). At the same time, it is seen that the "delivery flexibility" has the lowest average (3.20). When the performance criterion of the enterprise is evaluated in general terms, the significant attention given to delivery is remarkable.

\subsection{Testing the Research Hypothesis}

In this part of the study, the hypotheses of the research have been tested. In this framework, first of all, correlation analysis was performed and the relationship between the variables was determined. To determine the type of correlation analysis, firstly, Kolmogorov Smirnov Test was applied to the scales. As a result of the analysis, normal distribution was observed. Therefore, Pearson Correlation was performed to determine the relationship between the variables. The relationship between agile manufacturing and logistics performance is presented in Table 4 .

Table 4. Correlation Analysis

\begin{tabular}{lcccc}
\hline Variables & Mean & Standard Deviation & $\mathbf{( 1 )}$ & (2) \\
\hline Agile Manufacturing (1) & 3.73 & 0.63 & 1 & \\
\hline Logistics Performance (2) & 3.36 & 0.43 & $.553^{*}$ & 1 \\
\hline
\end{tabular}

Notes: (i) $\mathrm{n}=65$, (ii) ${ }^{*} \mathrm{p}<0.001$.

In order to measure the cause and effect relationship between agile manufacturing and logistics performance, firstly, the relationship between the variables was examined. As a result of the correlation analysis performed in this context, a positive and moderate (0.553) relationship was found between those variables. Based on this relationship, the cause and effect effects were researched and the research hypothesis was tested.

With the determination of agile manufacturing and logistics performance relationship, the research hypothesis developed in line with the main purpose of the research and the research question has been tested. In order to determine the effect of agile manufacturing on logistics performance, or in other words, to determine the cause and effect relationship, classical regression analysis has been performed. The results are presented in Table 5.

Table 5. Regression Analysis: Logistics Performance

\begin{tabular}{|c|c|c|c|c|c|c|}
\hline Dependent Variable & $\Delta \mathbf{R}^{2}$ & $\begin{array}{c}\text { Independent } \\
\text { Variable }\end{array}$ & Beta & Std. Error & $\mathbf{t}$ & $\mathbf{F}$ \\
\hline \multirow{2}{*}{ Logistics Performance } & \multirow{2}{*}{0.295} & Constant Term & 1.959 & 0.271 & 7.238 & \multirow{2}{*}{$27.730^{*}$} \\
\hline & & Agile Manufacturing & 0.377 & 0.072 & 5.266 & \\
\hline
\end{tabular}

Note: ${ }^{*} \mathrm{p}<0.001$. 


\section{E. Gelmez - M. Zerenler 12/4 (2020) 4142-4150}

When Table 5 is examined, it is seen that the proposed model is not statistically significant $(F=27.730 ; \mathrm{p}<0.001)$. When the table is examined in detail, it is seen that the degree of explanation of the logistics performance of agile manufacturing is at an acceptable level (0.295). At this point, when the hypothesis established within the scope of the research is evaluated; considering the variance value and the significance of the model, it is seen that logistics performance can be explained by agile manufacturing. Results in Table 5 support the research hypothesis "Agile manufacturing has a positive effect on logistics performance". As a result of the analysis performed in this context, the research question can be answered as "Agile manufacturing has an effect on logistics performance". At the same time, when this result is compared with the literature; it is seen that in the study by Zelbst et al. (2010) the level of explanation of the logistics performance of agile manufacturing is 0.362. Therefore, the hypothesis Zelbst et al. (2010) that suggests that "agility affects logistics performance directly and positively" has been accepted. Thus, it can be suggested that the result obtained in this study is similar to the literature.

\section{Conclusion and Suggestions}

The main aim of this study is to determine the effect of agile manufacturing on logistics performance. In line with this basic purpose, a survey was conducted on textile companies operating in Konya, Turkey.

As a result of the analysis; it has been concluded that agile manufacturing practices and logistics performances of enterprises are found above average. At the same time, it has been determined that logistics performance can be explained by agile manufacturing. Accordingly, the basic hypothesis established within the scope of the research has been accepted. The sector and province where the surveys are applied are generally SMEs. However, the importance given by businesses to flexibility and agility has been confirmed on this sample. As a matter of fact, Konya industry attracts attention with its growing structure and business practices. For businesses within the scope of the research; it can be understood with the importance they attach to delivery that they are well aware of the agile manufacturing concept and that they are aware that competition should be carried out accordingly.

Agile manufacturing can be considered as a structure where each company can develop its own business strategies and products. This structure is supported by three main sources, namely, innovative management structure and organization; talent base of knowledgeable and powerful staff, and flexible and smart technologies. Agility is achieved by integrating these resources into a coordinated and interdependent system (Srivastava et al., 2011: 225). Accordingly, in line with the findings obtained within the scope of the research, the following suggestions can be made to business managers:

- Businesses can increase their ability to meet and exceed product quality levels.

- Businesses can take care to act faster in introducing new products to the market.

- Businesses can take advantage of their agile manufacturing strategies by harmonizing agile manufacturing strategies to business strategies in order to strengthen their negative processes and further increase their positive processes.

The most important limitation of this research is that the universe consists of textile companies operating in Konya. This is a result of time and cost constraints. When evaluated from this point of view, it can be suggested that future studies may contribute to the literature performing the study on different sectors or on the same sector but on the country level. 


\section{E. Gelmez - M. Zerenler 12/4 (2020) 4142-4150 \\ References}

Agarwal, A., Shankar, R. and Tiwari, M. K. (2006). Modeling the metrics of lean, agile and leagile supply chain: An ANP-based approach, European Journal of Operational Research, 173 (1), 211-225.

Aktepe, C. and Çiftçi, H. S. (2017). Türkiye'de faaliyet gösteren karayolu yük taşıma kooperatiflerinin uluslararası taşımacılığa yönelik inovasyon, girişimcilik ve işbirliği eğilimleri üzerine keşifsel bir araştırma, Üçüncü Sektör Sosyal Ekonomi, 52 Özel Sayı, 836-886.

Aktepe, C. (2019). The future of international road freight transport companies in Turkey: Challenges and solutions, Journal of Business Management And Economic Research, 3 (4), 45-59.

Altunışık, R., Coşkun, R., Bayraktaroğlu, S. and Yıldırım, E. (2010). Sosyal Bilimlerde Araştırma Yöntemleri SPSS Uygulamalı, 6.Baskı, Ankara: Sakarya Kitabevi.

Ballou, R. H. (1997). Business logistics: Importance and some research opportunities, Gestão \& Produção, 4 (2), 117-129.

Başkol, M. (2010). Lojistik ve lojistik yönetimi, Bartın Üniversitesi İktisadi ve İdari Bilimler Fakültesi Dergisi, 1 (2), 47-64.

Bayat, T. and Özdemir, Ş. (2016). Yeni bir lojistik performans endeks oluşturmak için gerekli olan kriterlerin belirlenmesi üzerine araştırma, V. Ulusal Lojistik ve Tedarik Zinciri Kongresi, 603-611.

Bayraktutan, Y. and Özbilgin, M. (2015). Lojistik maliyetler ve lojistik performans ölçütleri, Maliye Araştırmaları Dergisi, 1 (2), 95-112.

Cho, H., Jung, M. and Kim, M. (1996). Enabling technologies of agile manufacturing and its related activities in Korea, Computers \& Industrial Engineering, 30 (3), 323-334.

Christopher, M. (2011). Logistics \& Supply Chain Management, Fourth Edition, Financial Times Prentice Hall.

Green Jr, K. W., Whitten, D. and Inman, R. A. (2007). The impact of timely information on organisational performance in a supply chain, Production Planning \& Control, 18 (4), 274-282.

Gunasekaran, A. (1999a). Agile manufacturing: A framework for research and development, International Journal of Production Economics, 62, 87-105.

Gunasekaran, A. (1999b). Design and implementation of agile manufacturing systems, International Journal of Production Economics, 62 (1-2), 1-6.

Gürbüz, S. and Şahin, F. (2018). Sosyal Bilimlerde Araştırma Yöntemleri, Gözden Geçirilmiş Güncellenmiş 5. Baskı, Ankara: Seçkin Yayıncılık.

Güzel, D. (2013). İmalatçı KOBİ'lerin çeviklik açısından incelenmesi: Erzurum ili örneği, Afyon Kocatepe Üniversitesi İktisadi ve İdari Bilimler Fakültesi Dergisi, 15 (1), 183-197.

Hallgren, M. and Olhager, J. (2009). Lean and agile manufacturing: External and internal drivers and performance outcomes, International Journal of Operations \& Production Management, 29 (10), 976-999.

Inman, R. A., Sale, R. S., Green Jr, K. W. and Whitten, D. (2011). Agile manufacturing: Relation to JIT, operational performance and firm performance, Journal of Operations Management, 29 (4), 343-355.

Iqbal, T., Huq, F. and Bhutta, M. K. S. (2018). Agile manufacturing relationship building with TQM, JIT, and firm performance: An exploratory study in apparel export industry of Pakistan, International Journal of Production Economics, 203, 24-37.

Islamoğlu, A. H. and Alnıaçık, , Ü. (2016). Sosyal Bilimlerde Araştırma Yöntemleri (SPSS Uygulamal), Gözden Geçirilmiş ve Genişletilmiş Beşinci Baskı, Beta Basım Yayım Dağıtım: İstanbul.

Kasap, G. C. and Peker, D. (2009). Çevik üretim: Otomotiv ana sanayinde faaliyet gösteren bir işletmenin çevikliğinin ortaya konmasına yönelik bir araştırma, Elektronik Sosyal Bilimler Dergisi, 8 (27), 57-78.

Lee, N. C. A., Wang, E. T. G. and Grover, V. (2020). IOS drivers of manufacturer-supplier flexibility and manufacturer agility, The Journal of Strategic Information Systems, 101594. 


\section{E. Gelmez - M. Zerenler 12/4 (2020) 4142-4150}

Meade, L. M. and Sarkis, J. (1999). Analyzing organizational project alternatives for agile manufacturing processes: An analytical network approach, International Journal of Production Research, 37 (2), 241-261.

Nabass, E. H. and Abdallah, A. B. (2019). Agile manufacturing and business performance: The indirect effects of operational performance dimensions, Business Process Management Journal, 25 (4), 647-666.

Neeraja, B., Mehta, M. and Chandani, A. (2014). Supply chain and logistics for the present day business, Procedia Economics and Finance, 11, 665-675.

Sekaran, U. (2003). Research Methods for Business: A Skill Building Approach. (J. Marshall, \& P. M. Fadden, Dü) New York: Fourth Edition.

Sezen, B., Yılmaz, C. and Gezgin, G. (2002). Lojistik işlevinin pazarlama ve üretim birimleri arasındaki bağlayıcı rolü ve işletme performansı üzerindeki etkileri, Dokuz Eylül Üniversitesi İktisadi İdari Bilimler Fakültesi Dergisi, 17 (2), 133-146.

Sezen, B. (2005). The role of logistics in linking operations and marketing and influences on business performance, Journal of Enterprise Information Management, 18 (3), 350-356.

Sharifi, H. and Zhang, Z. (2001). Agile manufacturing in practice-Application of a methodology, International Journal of Operations \& Production Management, 21 (5/6), 772-794.

Srivastava, P., Khanduja, D., Agrawal, V. and Grover, N. (2011). Agile manufacturing: Concepts and evolution, International Journal of Science and Advanced Technology, 1 (9), 224-229.

Tanoğlu, İ. M. (2018). Çevik Üretim ve Bir Uygulama Çalışması, Necmettin Erbakan Üniversitesi Fen Bilimleri Enstitüsü, Yüksek Lisans Tezi, Konya.

Thilak, V. M. M., Devadasan, S. R. and Sivaram, N. M. (2015). A literature review on the progression of agile manufacturing paradigm and its scope of application in pump industry, The Scientific World Journal, 19.

Timms, S., Ogle, T., Jackson, M. and Cooper, C. (2000). Agile manufacturing processes, http://icas.org/ICAS_ARCHIVE/ICAS2000/PAPERS/ICA0591.PDF (Date Accessed: 11.10.2019).

Udokporo, C. K., Anosike, A., Lim, M., Nadeem, S. P., Garza-Reyes, J. A. and Ogbuka, C. P. (2020). Impact of lean, agile and green (LAG) on business competitiveness: An empirical study of fast moving consumer goods businesses, Resources, Conservation and Recycling, 156, 104714.

USAID I DELIVER PROJECT, Task Order 1. (2011). The Logistics Handbook: A Practical Guide for the Supply Chain Management of Health Commodities, Arlington, Va.: USAIDIDELIVER PROJECT, Task Order 1.

Ustasüleyman, T. (2008). Çevikliğin işletme performansına etkisine yönelik yapısal bir model önerisi, Gazi Üniversitesi İktisadi ve İdari Bilimler Fakültesi Dergisi, 10 (2), 161-178.

Vázquez-Bustelo, D., Avella, L. and Fernández, E. (2007). Agility drivers, enablers and outcomes: empirical test of an integrated agile manufacturing model. International Journal of Operations \& Production Management, 27 (12), 1303-1332.

Yazıcığlu, E. and Erdoğan, S. (2014). SPSS Uygulamalı Bilimsel Araştırma Yöntemleri, Gözden Geçirilmiş Yenilenmiş 4. Baskı, Ankara: Detay Yayıncılık.

Zelbst, P. J., Green Jr, K. W., Abshire, R. D. and Sower, V. E. (2010). Relationships among market orientation, JIT, TQM, and agility. Industrial Management \& Data Systems, 110 (5), 637-658.

Zerenler, M. (2007). Information technology and business performance in agile manufacturing: An empirical study in textile industry. International Conference on Information Technology (ITNG'07), IEEE, 543-549. 